\title{
ADDRESS OF THANKS TO THE SPONSORS AND JURY OF THE TRUMAN CAPOTE AWARD FOR LITERARY CRITICISM IN MEMORY OF NEWTON ARVIN (2009)
}

Though not a true numismatist, I take pleasure in coins. One is instructed not to handle them with ungloved fingers, for fear of rubbing off the "luster" or "bloom." Even so, I confess to enjoying them as objects. I would even carry one or two on long-haul flights (when I took these; I am no longer able to) where others might carry a lucky pebble as tactile comforters.

My favorite coin is probably the English "cartwheel" tuppence of 1797. It was what the experts call an "intrinsic value" coin; this is to say that it contained exactly two pennies' worth of copper as the price stood at the date of its issue. It is not a pretty coin; it is indeed uncouth, thick, and with a circumference equal to that of a silver crown, a much more valuable and aesthetically pleasing coin.

At that time the English pound sterling contained two hundred and forty pence. Therefore $£ 1.00$ would comprise one hundred and twenty of these massive tokens; to carry $£ 100.00$ a person would probably need to use a pack-horse.

I am, in my approach to literature and literary criticism, an "intrinsic value" person. I try to imagine it as a palpable quality; if a poem or a prose passage succeeds, I tell myself, then one ought to be able to weigh it in a craftsman's pair of scales. An objection can be made that writers whom I revere and who proclaim intrinsic value-Ruskin and others-are in fact pursuing a phantom. The "cartwheel" tuppence of 1797 would itself have ceased to be an intrinsic value coin one day after its minting if the price of copper had shifted on the exchanges. It would seem then that I am deluded and that in actuality intrinsic value cannot be weighed in literature, and that it is the thing most abhorrent to the "true" minters: a promissory note. I would concede that literature is in most cases little more than a set of promissory notes but insist that this is not so in every case. The good poem, the

The Iowa Review

University of lowa 
good piece of prose, is at once the promissory note and its essential redemption.

I can hardly begin to imagine what Truman Capote would have made of this present book [Collected Critical Writings] on which the trust established in his name has generously bestowed its prize for 2009. Consummate stylist that he is, it would have seemed to him, perhaps, unwieldy, ungainly, even uncouth. What the author of In Cold Blood and I may nonetheless have in common is a sense that "publike Dyscrasy" (to quote a seventeenth-century theologian) is at the root of common existence in the liberal democracies and that when its converse eucracy is polemically asserted by the state (as in Nazi Germany or the Stalinist Soviet Union) tyranny far worse than mere plutocratic lobbying ensues. Not that the plutocratic lobby is anything other than foully debilitating to the energies of creation and criticism.

It is a paradox or oxymoron that must be lived with: one cannot be original without at the same time being deeply indebted. In my critical writings I am not acknowledging a personal debt to the past, because acknowledgment in that form can be a merely patronizing gesture (as a best-selling historical novelist might acknowledge her research team). My overriding concern is to bring to general attention the inescapable involvement of present with past and, perhaps even more urgently, of one's own present with the present as it is experienced by others. The metamorphic power of great writing is that it is able to change this passive involvement or impaction into an active quality of perception.

No one can be radical who does not understand her roots. But I persist in regarding a writer's essential roots as being in the broadest sense semantic rather than familial or racial. What was once said, concerning the various interferences of critics, by Henry Rago, a former editor of Poetry, could hardly be bettered: "when the language is that of the imagination, we can be grateful enough to read that language as it asks to be read: in the very density of the medium, without the violence of interpolation or reduction." In my perplexity, "intrinsic value" 
is a shorthand tag for acknowledging the writer's inescapable engagement with the density of the medium.

I would suppose Rago to mean that the work's commingling of agitation and repose encourages in the cognate reader a reciprocal attention. The repose is of course the finality, as it must appear, of formal utterance. The agitation is one of desire, by the writer to attain rest, by the reader also to attain rest, though of a somewhat different kind. Writer and reader alike desire to rest in the work.

I do not mean enjoyment. To enjoy is to draw something not-self into one's own sphere of influence and entertainment. Its incapacity is in proportion to its sentimentality. Joy is something quite other and could properly be used of the meeting of minds drawn to each other in the making and receiving of a consummate piece of work. Coleridge's marginalia show something of the quality I desiderate, but his was a mind of rare attainment, and it would be a sad day for literature if only an attentiveness of his caliber could be proposed as that of the reader whom Rago evidently has in mind. I have periods of near-despair when it does seem to me that this is what I am asking.

That it should come to this, if it is indeed coming to this, is regrettable for everyone concerned. But the alternative, which embodies worse forms of obscurantism in the guise of openness or confession, is yet more regrettable. For anyone to claim that what gives true fire to their damp squibs of inspiration is their privileged psychic or cultural self-regard seems to me an obscurantism far more damaging than the skewed intellectualism of MacDiarmid's Hymns to Lenin or Pound's Jefferson and/or Mussolini, vicious though this is.

Until I left the USA in 2006, I owned for a time a book which had been in the library of the classicist and critic Donald CarneRoss and which contained his marginalia. To my grief, it was one of a number of books that went astray during my relocation to the United Kingdom. As I recall—and my memory is now faulty-I am indebted to Carne-Ross for his penciled note on the "ontological

The Iowa Review 
reader": something about ontological readers not passively reflecting their own pathos.

This strikes me as a magnificent perception about a radical kind of relationship between reader and writer and indeed between the writer and her own work: rightly considered it is needful to add. It is my belief that the majority of writers (and readers) does not grasp the nature of the relationship between themselves and their own writing (and reading).

"Publike dyskrasy" is a term I found recently in the writings of Bishop Jeremy Taylor (1613-1667). In terms of civic observation it can be ranked with Ruskin's "illth," the "anarchical plutocracy" of William Morris, and the "Banker's Olympus" of Henry Adams (and later P. Wyndham Lewis). As Yeats asked in August 1934, "What if the Church and the State / Are the mob that howls at the door!"

The overriding civic emotion of many of us today must be one of desperate fatalism. It may resemble the emotions of those survivors of Anglo-Saxon civilization during the two or three hundred years subsequent to the Norman Conquest of 1066. Indeed those terrible bankers and brokers who deemed themselves free to take jus primae noctis with the savings and livelihoods of ordinary people, in the years prior to 1929 and 2008, greatly resemble in their amoral self-gratification and presumption of entitlement the tribal warlords who followed the Norman conqueror. In my rage and despair, I find myself reciting this potent Victorian mythos, disputable though it must be.

In my critical writings I take Thomas Nashe, Robert Burton, and Jonathan Swift to be the three great early modern masters of the dyscratic, as Langland was the great verse-master of medieval dyscracy. Nashe, Burton, and Swift battle the dyscracy within the structures of their own sentences and paragraphs. Not only are the formal arts of rhetoric subjected to previously unmeasured strains, but they also develop new strains as a virus may be said to do. Moreover, that element of fatalism mutates in their writings into something richer and inexorable, into games with the fatal illogic of the world as this can be shown to be subject to comic redemption: the oxymoron of mishap 
and haplessness changing to the paradox of ebullience and grace. These qualities I find in abundance in Nashe and Burton, less evidently in Swift.

With Jeremy Taylor, whose "publike Dyskrasy" has ranged like a motto-phrase throughout this address, the focus, though not the general circumference, shifts significantly. Coleridge spoke of his "great \& lovely mind" but the loveliness is more than a happy accident of temperament. It is a willed instrument of persuasion whereby midseventeenth-century Anglican royalism is shown at all times to be more comely than sectarian anarchy. Nashe and Burton have great minds, and each practices an Anglican form of polity, but they are not "lovely" in quite the way that Coleridge means us to apply the term to Taylor. Even so, and at this point he most closely resembles the authors already named, Taylor's roots are as much in classical comedy as in the Hebrew Bible and New Testament: "These in phantastick semblances declare a severe councell and usefull meditation." He is Petronian in his vision of the oxymoronic dominion of carnality.

In pursuing my reading of these authors I have found myself becoming more and more Petronian in attitude and rhetorical management. In recent years, I suspect, these elements have become engrained and engrafted in my own poetry, though this is a category of work which I vowed I would not stray into when I began drafting this address.

The Iowa Review 